\title{
Expression of $M x$ exon-13 SNPs in Kampong-Laying Type (Kamper) chicken crossbreeds of female Lohmann brown-classic and male Pelung
}

\author{
DESIANA AFIFAH ${ }^{1}$, INDRA LESMANA ${ }^{1}$, SOENARWAN HERY POERWANTO ${ }^{2}$, TRI JOKO ${ }^{2}$, \\ I WAYAN SWARAUTAMA MAHARDHIKA ${ }^{1, \bullet}$, BUDI SETIADI DARYONO ${ }^{1, \bullet \bullet}$ \\ ${ }^{1}$ Gama Ayam Research Team, Laboratory of Genetics and Breeding, Faculty of Biology, Universitas Gadjah Mada. Jl. Teknika Selatan, Sekip Utara, \\ Sleman 55281, Yogyakarta, Indonesia. `email: i.wayan.sm@mail.ugm.ac.id, ^^ bs_daryono@mail.ugm.ac.id \\ ${ }^{2}$ Laboratory of Animal Systematics, Faculty of Biology, Universitas Gadjah Mada. Jl. Teknika Selatan, Sekip Utara, Sleman 55281, Yogyakarta, \\ Indonesia
}

Manuscript received: 11 December 2019. Revision accepted: 19 March 2020.

\begin{abstract}
Afifah D, Lesmana I, Poerwanto SH, Joko T, Mahardhika IWS, Daryono BS. 2020. Expression of Mx exon-13 SNPs in Kampong-Laying Type (Kamper) chicken crossbreeds of female Lohmann brown-classic and male Pelung. Biodiversitas 21: $1483-1487$. The Gama Ayam Research Team has implemented marker-assisted selection (MAS) in selective breeding to provide a faster, more accurate, and more reliable selection of chicken. $M x$ gene expression has a vital role in chicken disease resistance. This research aimed to investigate the expression of $M x$ exon-13 single nucleotide polymorphisms (SNPs) in the population of female Layer Lohmann Brown-Classic, male Pelung, and its progenies Kampong-Laying Type (Kamper) chicken. The G1892A mutation in Mx exon-13 resulted in a change in the amino acid 631 of $M x$. The substitution of serine to asparagine favored the ability of chickens to acquire immunity against viral diseases, including avian influenza. Asparagine (A allele) at position 631 is specific to $M x^{+}$(resistant), whereas serine ( $\mathrm{G}$ allele) is specific to $M x^{-}$(susceptible). DNA was amplified using the forward primer 5'-GCACTGTCACCTCTTAATAGA-3' and the reverse primer 5'-GTATTGGTAGGCTTTGTTGA-3' and then sequenced using the Sanger sequencing method. Four SNPs were obtained through $M x$ sequence alignment. They consisted of four substitutions (A20734T, C20737T, A20766G, and A20893G) with one haplotype. Mx exon-13 SNPs were detected in Pelung and Kamper. Therefore, Kamper chicken inherited the disease resistance gene of Pelung and could be a strong candidate for parental generation in the further selective breeding program.
\end{abstract}

Keywords: AI, Kamper, $M x$ gene, resistance, SNPs

\section{INTRODUCTION}

Since 2008, the Gama Ayam Research Team has conducted several selective breeding programs with a wellconstructed breeding structure and a native chicken breed to produce meat-type and laying-type chicken breeds with disease resistance. Selective breeding between Pelung Blirik Hitam and Broiler Cobb 500 produced the hybrid chicken $\mathrm{F}_{1}$ Broiler or Kambro (Kampung-Broiler Type; Mahardhika and Daryono 2019). In 2013-2014, this research team successfully bred the $\mathrm{F}_{1}$ Kamper, a chicken breed that inherited the characteristics of female Lohmann Brown-Classic and male Pelung (Habibah et al. 2019, unpublished data). This research team also implemented marker-assisted selection (MAS) on numerous studies by using several genes. Tanjung et al. (2019) investigated the expression of the Myostatin gene in Gama chicken. Selective breeding in chicken is conducted based on egg productivity, meat productivity, and disease resistance. Diseases infecting chickens in tropical regions, such as Indonesia, include avian influenza (AI), Newcastle disease (ND), and chronic respiratory disease. The spread of the avian influenza A (H5N1) virus started when an outbreak occurred in poultry in August 2003 (Pracoyo 2009). Pracoyo (2009) also stated that the first human case was first recorded in July 2005 in Tangerang Municipality and then in eight provinces. In December 2008, the total cases increased by up to 139 people, and 113 of them died (Pracoyo 2009). To overcome the spread of AI in chickens, some researchers investigated the assembly, especially breeding, of chickens; when compared the resistance to AI of $63 \%$ of the local chicken population in Indonesia is relatively higher than that of imported broiler and layer chickens (Maeda 2005). Therefore, the native chicken breed can be further improved for selective breeding.

MAS can be applied in selective breeding to provide a faster, more accurate, and more reliable selection of chicken. $M x$ molecular marker can be used to identify the expression and probability of disease resistance in Kamper chicken. Pagala et al. (2017) found that Mx|Hpy 81 is polymorphic in all genotyped chicken strains. Mx|Hpy 81 may be used as a genetic marker of resistance to AI and ND in Indonesian native chickens (Pagala et al. 2017). Permatasari et al. (2015) stated that $M x$ (GenBank accession number: DQ788615) is located on chromosome 1 having a fragment length of 20,767 base pairs (bp) and consisting of 13 exons. The $G / A$ polymorphism on exon-13 at nucleotide position 1,892 of coding the sequence of $M x$ results in changes in 631 amino acids of the $M x$ protein. Fourteen amino acid variants have been identified in the $M x$ protein from multiple chicken breeds, whose antiviral activity is seemingly linked to one amino acid variant at position 631 (S631N; Fulton et al. 2014). Fulton et al. (2014) also reported $M x$ polymorphisms in many chicken 
breeds, including Australorp, Fayoumi, Japanese native chickens, Indonesian native chickens, White Leghorns, broilers, and inbred laboratory lines. Pagala et al. (2017) found that Kampong and Tolaki chickens are resistant to virus attacks (e.g., AI and ND) because of the flow of the A allele, which causes serine (AGT) to change into asparagine (AAT). The presence of asparagine (A) at exon 13 indicates that chickens are resistant to viral infections; by contrast, chickens are vulnerable to virus attacks when a base mutation occurs in serine (G) (Ko et al. 2002; Watanabe 2003; Ko et al. 2004; Pagala et al. 2017).

The parental generation of the breeding tree of Kamper chicken includes Pelung chicken as the male generation. The $M x$ gene expression is expected to reside in Indonesian native chicken breeds. The $M x$ expression and its correlation with growth performance in Kamper chicken have never been explored. In this research, the relation of $M x$ polymorphism associated with the growth of Kamper chicken was investigated.

\section{MATERIALS AND METHODS}

The research was conducted in January 2017-June 2018 at Pusat Inovasi Agroteknologi (PIAT) UGM, Berbah, Sleman, Yogyakarta, and at the Laboratory of Genetics and Breeding, Faculty of Biology UGM. Whole blood samples used in this research are female Layer Lohmann BrownClassic, male Pelung, its progenies generation KampongLaying Type (Kamper) chicken and Broiler Cobb 500 chicken. Feeds and equipments used in this research are chicken feeds (BR-I and AD-II), supplements, $1 \mathrm{~mL}$ syringe, ethylenediaminetetraacetic acid (EDTA), TE buffer, collection tube, master mix PCR (MyTaq HS Red Bioline), agarose, $70 \%$ alcohol, $\mathrm{ddH}_{2} \mathrm{O}$, FloroSafe DNA stain (BIO-5170, 1st BASE, Malaysia), 100 bp DNA ladder (Bioron), chelex $5 \%$ solution, $18 \mu \mathrm{L}$ of $0.05 \mathrm{M}$ DTT, 10 $\mathrm{mg} / \mathrm{mL}$ proteinase $\mathrm{K}, 1 \times \mathrm{TAE}, 10 \times \mathrm{TAE}, \mathrm{PCR}$ thermocycler (Bio-Rad), PCR tube (Biologix), waterbath, centrifuge, pipette tips (blue, yellow, and white), $1.5 \mathrm{~mL}$ microtube, and UV transilluminator (Geldoc). This study was performed under the Animal Welfare Act of Indonesia and all procedures involving the handling of animals were approved by the local office of occupational and technical safety (Ethical Clearance Commission of Laboratorium Penelitian dan Pengujian Terpadu, Universitas Gadjah Mada, Yogyakarta No: 00038/04/LPPT/VI/2018).

\section{Procedures}

Chicken maintenance, body weight data records, and whole blood sampling

The chicken population groups were randomly sampled as follows: a) layer Lohmann Brown-Classic (n: 5), b) Pelung (n: 5), c) Broiler Cobb 500 (n: 5), and d) KampongLaying Type (Kamper) (n: 5). Each chicken population group was reared starting from day-old-chick (DOC) until 7-weeks-old in a semi-intensive rearing system at PIAT UGM. Ad libitum standard feed diets of BR-I (0-4 weeks old) and AD-II (4-7 weeks old) were supplied by PT., Japfa
Comfeed. The body weight in each week was recorded with a semi-analytical scale. Chicken blood samples were obtained using a syringe $(1 \mathrm{~mL})$, placed in EDTA $+1.5 \mathrm{~mL}$ microtube, and stored in a freezer at the temperature of -20 ${ }^{\circ} \mathrm{C}$.

\section{DNA isolation and sequencing}

Whole blood DNA was isolated using the Chelex method. In this procedure, $10 \mu \mathrm{L}$ of the blood sample was added to $1 \mathrm{~mL}$ of TE buffer and then centrifuged at 13000 rpm for $13 \mathrm{~min}$. The supernatant was removed, the pellet was extracted, and a $5 \%$ chelex solution, $18 \mu \mathrm{L}$ of $0.05 \mathrm{M}$ DTT, $2 \mu \mathrm{L}$ of $10 \mathrm{mg} / \mathrm{mL}$ proteinase $\mathrm{K}$ were added. The solutions were incubated at $56{ }^{\circ} \mathrm{C}$ for $2 \mathrm{~h}$, vortexed for homogenization for $15 \mathrm{~min}$, further incubated for $8 \mathrm{~min}$, and centrifuged for $3 \mathrm{~min}$, The supernatant was transferred to a microtube and stored in a freezer at the temperature of $-20{ }^{\circ} \mathrm{C}$. The DNA fragment was amplified with $25 \mu \mathrm{L}$ of PCR solution consisting of $12.5 \mu \mathrm{L}$ of Mastermix PCR (MyTaq HS Red Bioline), $1.25 \mu \mathrm{L}$ of forwarding primer (5'-GCACTGTCACCTCTTAATAGA-3'), and $1.25 \mu \mathrm{L}$ of reverse primer $\left(5^{\prime}\right.$-GTATTGGTAGGCTTTGTTGA-3'), 5 $\mu \mathrm{L}$ of DNA samples, and $5 \mu \mathrm{L}$ of $\mathrm{ddH}_{2} \mathrm{O}$. PCR amplification was performed using a thermal cycler PCR machine with a predenaturation condition at $95{ }^{\circ} \mathrm{C}$ for 3 min, denaturation at $95{ }^{\circ} \mathrm{C}$ for $15 \mathrm{~s}$, annealing at $60{ }^{\circ} \mathrm{C}$ for $15 \mathrm{~s}$, extension at $72{ }^{\circ} \mathrm{C}$ for $25 \mathrm{~s}$, and post extension at 72 ${ }^{\circ} \mathrm{C}$ for $5 \mathrm{~min}$ (Sironi et al. 2010). The PCR products were detected through electrophoresis on $2 \%$ agarose gel in a submarine electrophoresis system (Mupid-EXU) device. Agarose gel was initially prepared by dissolving $0.8 \mathrm{~g}$ of agarose powder in $40 \mathrm{~mL}$ of $1 \times$ TAE. Then, $4 \mu \mathrm{L}$ of FloroSafe was added to this solution and inserted into a mold equipped with a comb. The solidified gel was placed in an electrophoresis chamber and soaked with $0.5 \times$ TAE. Next, $5 \mu \mathrm{L}$ of the ladder and PCR samples were inserted into gel wells. The electrophoresis system was set at $100 \mathrm{~V}$ for $20 \mathrm{~min}$. Lastly, observations were performed under ultraviolet light $(\lambda=260 \mathrm{~nm})$. All the experimental animals used in this study were cared for and maintained throughout the experiments in strict accordance with the ethics and biosecurity guidelines approved by the Institutional Animal Care and Use Committee of UGM, Yogyakarta, Indonesia. DNA sequencing was carried out by PT. Genetika Science Indonesia (Ruko Puri Mansion, Blok A, Jalan Lingkar Luar No. 19, Kembangan Selatan, Kembangan, West Jakarta City, Special Capital Region of Jakarta).

\section{Data analysis}

The body weights of Pelung, Broiler Cobb 500, and Kampong-Laying Type (Kamper) chickens were then analyzed with ANOVA analysis. DNA was sequenced through the Sanger sequencing method and analyzed with Gene Studio software. The correlation between body weight and $M x$ expression was analyzed using Pearson's correlation with IBM@ SPSS $\odot$ version 21. 


\section{RESULTS AND DISCUSSION}

Crossbreeds between female Lohmann Brown-Classic and male Pelung produced the progenies generation Kampong-Laying Type (Kamper). Ernanto (2017) concluded that the egg productivity of Kamper is higher (HDP: 140 eggs/300 days production) and its growth rate is relatively faster than those of Pelung chicken. Visual observation has shown that Kamper has several distinguishing traits, including white shank, golden and brown-barred feather, and single comb (Figure 1).

\section{Bodyweight}

Based on the 7 weeks of bodyweight measurement of each chicken population group under semi-intensive rearing system with standard feed diet the results are as follows, Pelung (289.4 g), Kampong-Laying Type (Kamper) (441.2 g), and Broiler Cobb 500 (2897 g; Figure $2)$. Fisher's LSD post hoc analysis revealed that the growth rate of Kamper was significantly faster than that of Pelung $(\mathrm{p}<0.05)$

\section{Mx gene polymorphisms}

$M x$ exon-13 was subjected to image analysis by using Gene Studio software, and the results revealed that the size of the DNA fragment from each sample $(n=16)$ was $300 \mathrm{bp}$ (Fig. 3). Pagala et al. (2017) reported a similar DNA fragment size of the DNA band of $M x$ in Tolaki chicken (299 bp). $M x$ exon-13 discovered in White Leghorn and New Hampshire chickens have a similar size of 300 bp (Pagala et al. 2017). Afterimage analysis, $M x$ amplicons were further analyzed with the Sanger sequencing method. The obtained sequence results were assembled using Gene Studio and then aligned with Clustal Omega to identify the polymorphic site.

Table 1 shows four SNPs of $M x$ were detected in Kamper and Pelung chickens and identified as a substitution mutation specified in several gene sites, namely, A20734T, C20737T, A20766G, and A20893G. They formed one haplotype in Kamper chicken. Three Kampong-Laying Type (Kamper) chickens formed one haplotype, and one Kamper chicken had the same nucleotide composition as the reference in GenBank ( $M x$ accession number: DQ788616.1).

Table 2 indicates that $M x$ polymorphisms were not significantly correlated with body weight but were positively and weakly correlated in the four SNPs sites of A20734T, C20737T, A20766G, and A20893G. Mx SNPs had no significant effect on the growth and bodyweight performance of Kamper chicken.

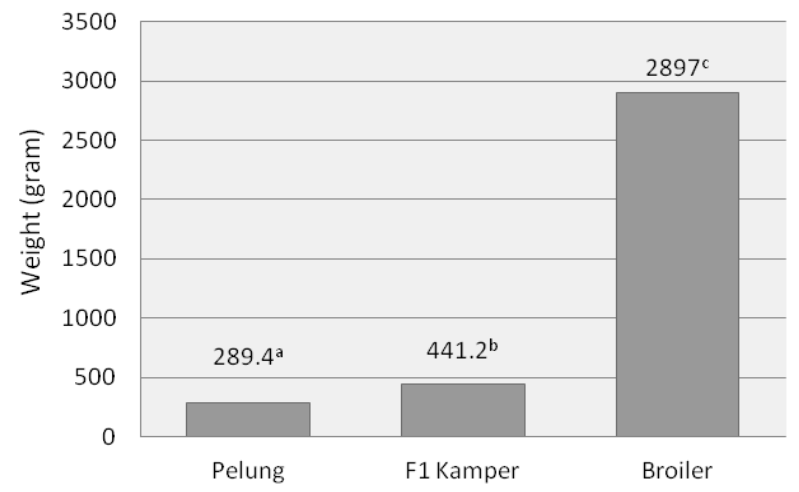

Figure 2. Bodyweight comparison of Pelung chicken, Kamper chicken, and Broiler Cobb 500 in 7 weeks. The averages with different superscripts differ significantly $(\mathrm{p}<0.05)$ as indicated by Fisher's LSD post hoc analysis.

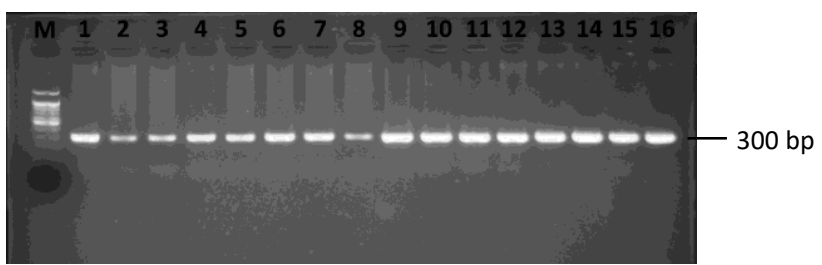

Figure 3. $M x$ gene visualization. M: 100 bp DNA ladder; 1-5: Kampong-Laying Type (Kamper); 6-10: Pelung; 11-16: Broiler Cobb 500.

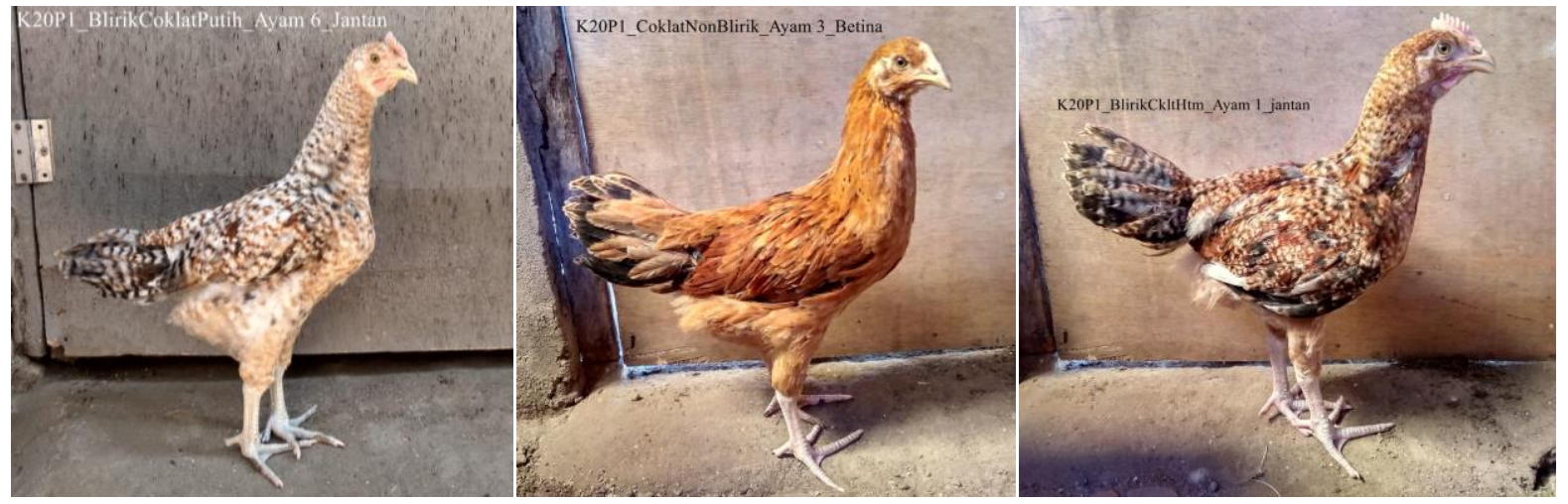

Figure 1. Phenotypic traits of Kamper chicken (Gama Ayam Research Team 2019) 
Table 1. Single nucleotide polymorphisms of Mx in Kamper and Pelung chickens

\begin{tabular}{|c|c|c|c|c|c|c|}
\hline \multirow[b]{2}{*}{ Sample codes } & \multicolumn{4}{|c|}{$M x$ polymorphism Exon-13 } & \multirow[b]{2}{*}{ Haplotype } & \multirow{2}{*}{$\begin{array}{l}\text { 7-week-old chicken } \\
\text { body weight } \\
\text { (gram) }\end{array}$} \\
\hline & $\begin{array}{c}\text { Substitution } \\
\text { A20734T }\end{array}$ & $\begin{array}{c}\text { Substitution } \\
\text { C20737T }\end{array}$ & $\begin{array}{c}\text { Substitution } \\
\text { A20766G }\end{array}$ & $\begin{array}{c}\text { Substitution } \\
\text { A20893G }\end{array}$ & & \\
\hline DQ788616.1 & $\mathrm{A}$ & $\mathrm{C}$ & $\mathrm{A}$ & $\mathrm{A}$ & Reference* & - \\
\hline 2 & $\mathrm{~T}$ & $\mathrm{~T}$ & $\mathrm{G}$ & $\mathrm{G}$ & 1 & 297 \\
\hline 3 & $\mathrm{~T}$ & $\mathrm{~T}$ & $\mathrm{G}$ & $\mathrm{G}$ & 1 & 488 \\
\hline 4 & $\mathrm{~T}$ & $\mathrm{~T}$ & $\mathrm{G}$ & G & 1 & 452 \\
\hline 5 & A & $\mathrm{C}$ & A & A & Reference* & 397 \\
\hline 6 & A & $\mathrm{C}$ & $\mathrm{A}$ & A & Reference* & 336 \\
\hline 7 & A & $\mathrm{C}$ & A & A & Reference* & 321 \\
\hline 10 & $\mathrm{~A}$ & $\mathrm{C}$ & $\mathrm{A}$ & $\mathrm{A}$ & Reference* & 231 \\
\hline
\end{tabular}

Note: *Reference refers to the DQ788616.1 Mx GenBank accession number.

Table 2. Correlation of $M x$ polymorphism with the bodyweight of Kamper chicken in 7 weeks

\begin{tabular}{|c|c|c|c|c|c|c|c|c|c|c|c|c|}
\hline \multirow{2}{*}{$\begin{array}{l}\text { Single nucleotide polymorphisms } \\
\text { Genotype }\end{array}$} & \multicolumn{3}{|c|}{$\begin{array}{c}\text { Substitution } \\
\text { A20734T }\end{array}$} & \multicolumn{3}{|c|}{$\begin{array}{c}\text { Substitution } \\
\text { C20737T }\end{array}$} & \multicolumn{3}{|c|}{$\begin{array}{c}\text { Substitution } \\
\text { A20766G }\end{array}$} & \multicolumn{3}{|c|}{$\begin{array}{c}\text { Substitution } \\
\text { A20893G }\end{array}$} \\
\hline & AA & AT & TT & $\mathrm{CC}$ & CT & TT & $\mathrm{AA}$ & $\overline{\mathrm{AG}}$ & GG & $\mathrm{AA}$ & $\mathrm{AG}$ & GG \\
\hline Genotype frequency & 0.25 & 0 & 0.75 & 0.25 & 0 & 0.75 & 0.25 & 0.75 & 0 & 0.25 & 0 & 0.75 \\
\hline Average body weight for 7 weeks & 397 & - & 412.3 & 397 & & 412.3 & 397 & 412.3 & - & 397 & - & 412.3 \\
\hline Correlation coefficient $(r)$ & \multicolumn{3}{|c|}{$0.092 *$} & \multicolumn{3}{|c|}{$0.092 *$} & \multicolumn{3}{|c|}{$0.092 *$} & \multicolumn{3}{|c|}{$0.092 *$} \\
\hline Significance & \multicolumn{3}{|c|}{$0.908^{\text {ns }}$} & \multicolumn{3}{|c|}{$0.908 \mathrm{~ns}$} & \multicolumn{3}{|c|}{$0.908^{\mathrm{ns}}$} & \multicolumn{3}{|c|}{$0.908^{\text {ns }}$} \\
\hline
\end{tabular}

Note: ns: nonsignificant ( $>0.05)$; * positively weak correlation (Pearson's correlation)

\section{Discussion}

The image analysis of $M x$ exon-13 via Gene Studio revealed that the size of the DNA fragment from each sample (n=16) was 300 bp (Fig. 3). Pagala et al. (2017) reported a quite similar DNA fragment size of the DNA band of $M x$ in Tolaki chicken (299 bp). Mx exon-13 discovered in White Leghorn and New Hampshire chicken has a similar size of 300 bp (Pagala et al. 2017). Permatasari et al. (2015) stated that $M x$ is a specific genetic marker of disease resistance in avian species, including chicken (Gallus gallus). Mx is located in chromosome 1 (GenBank accession number: DQ788615) having a fragment length of $20,767 \mathrm{bp}$ and consisting of 13 exons, 1115 bp coding regions, and 705 remaining amino acids (Permatasari et al. 2015). $M x$ has been linked to chicken immunity levels against viral diseases, such as AI and ND (Ko et al. 2002; Ko et al. 2004; Pagala et al. 2013; Pagala et al. 2017). $M x$ and the large GTPase protein it encodes are among the most studied interferon-stimulated antiviral effector molecules (Verhelst et al. 2013; Fulton et al. 2014). Their identity and names are based on their ability to inhibit the replication of viruses, specifically influenza virus (Verhelst et al. 2013; Fulton et al. 2014).

The frequency of $\mathrm{A} / \mathrm{G}$ alleles in chickens can be a genetic indicator of the level of chicken resistance to virus attacks (Ko et al. 2002). Sulandari et al. (2007) stated that the A/G allele distribution in the native chicken population (Pelung, Sentul, Kedu, Kedu Hitam, Kedu Putih, Cemani, Wareng, Merawang, Gaok, Kate, Kapas, Arab Gold, and Arab Silver) in Indonesia can be identified with an $M x$ genetic marker. The results of this research showed that nucleotide polymorphisms in $M x$ exon-13 were as follows:
1) $\mathrm{G}$ allele (GG genotype) is susceptible to AI virus; 2) A allele (AA genotype) is resistant to AI virus; 3) AG genotype can be resistant or susceptible to AI virus (Sulandari et al. 2007). Four $M x$ exon-13 SNPs were identified as follows: A20734T, C20737T, A20766G, and A20893G (Table 1). Pagala and Ulupi (2014) found a similar SNP A20766G substitution. Mx polymorphism at 20766 of the nucleotide site was identified as SingleNucleotide Polymorphism (SNP) with the substitution of $G T$ to $A T$ (A20766G). Substitution mutation alters the translation of serine $(A G T)$ into asparagine $(A A T)$. Asparagine $(A)$ in $M x$ exon-13 indicated chicken viral resistance known as $M x^{+}$, whereas serine $(G)$ translation indicated chicken susceptibility to viral infections known as $M x^{-}$(Maeda 2005). Three Kamper chickens had the $A G T$ genotype $\left(M x^{-}\right)$, whereas one Kamper chicken had the $A A T$ genotype $\left(\mathrm{Mx}^{+}\right)$. This finding demonstrated that Kamper chicken had an acquired immunity against viral infection through selective breeding by using Pelung, which has been known as one of the native chicken breeds expressing $M x$ in Indonesia.

Table 2 indicates the correlation of $M x$ polymorphisms with bodyweight was not significant, and a positive weak correlation was observed in four SNPs sites of A20734T, C20737T, A20766G, and A20893G. Mx SNPs had a nonsignificant effect on the growth and bodyweight performance of Kamper chicken. Fulton et al. (2014) reported the correlation between $M x$ SNP and several performance traits, including the egg productivity (MxCDS122) and rate of lay (MxCDS122, MxCDS351, MxCDS694, and MxCDS62), but Mx SNPs were not correlated with the bodyweight of chickens. Livant et al. 
(2007) found that Mxl exon-13 SNPs are significantly associated with the mortality rate and leg defects in broiler breeder chickens.

High body weight selection in broiler chickens and turkeys has resulted in a negative correlation in immune performance. The broilers selected for a high growth rate show lower antibody responses when they are challenged with sheep erythrocytes than those of a low BW line and a randomly bred control line (Knap and Bishop 2008). Kamper chicken has an inherited disease resistance allele of Pelung and grouped as a slow-growth broiler. The body weight gain and feed conversion of local chickens with AA and $A G$ types are significantly higher than those of chickens with the GG type. This finding was consistent with several previous studies, which showed that genotypes containing A alleles are positively associated with the weight of 40-day-old chickens in a poorly hygienic environment. These results supported earlier assumptions that a strong link exists between the character of disease resistance and the ability of livestock to produce.

Chicken productivity depends on environmental conditions and disease resistance adaptation. Livestock that has a good fitness level and can resist infections tends to display a better production performance (Knap and Bishop 2008). However, Pearson's correlation revealed that the polymorphism point (A20766G) related to the weight of 7 week-old chickens was not significant and positively very weak. A decisive conclusion on the correlation between $M x A 20766 G$ SNP and chicken body weight must be validated using a large population size. Genotyping results indicated that three Kamper chickens were susceptible to AI virus with $\mathrm{AG}$ genotype $\left(M x^{-}\right)$, and one Kamper chicken was resistant because of the AA genotype expression $\left(M x^{+}\right)$. MAS could be used as a precise and highly efficient tool in selective breeding. Kamper chicken generation could be selected based on these results to further improve this breed through continuous selective breeding.

\section{ACKNOWLEDGEMENTS}

In 2018, this research was funded by the STRANAS Grant (No. 1734/UN1/DITLIT/DIT-LIT/2018) from the Ministry of Research, Technology and Higher Education, Republic of Indonesia. In 2019, this research was further supported financially by the Applied Research Grant (Penelitian Terapan/PT No. 2830/UN1.DITLIT/DITLIT/LT/2019) from the Ministry of Research, Technology and Higher Education, Republic of Indonesia. The authors acknowledge the Gama Ayam Research Team, Gadjah Mada University, Yogyakarta, Indonesia, for helping maintain day-old-chick (DOC) and for conducting molecular analysis at the Laboratory of Genetics and Breeding.

\section{REFERENCES}

Ernanto AR. 2017. Asosiasi polimorfisme gen $P R L$ dan $I G F-1$ terhadap produktivitas telur ayam (Gallus gallus domesticus Linnaeus, 1758) $\mathrm{F}_{1}$ hasil persilangan ayam Pelung dan Layer. [Dissertation]. Fakultas Biologi. Universitas Gadjah Mada, Yogyakarta. [Indonesian]

Fulton JE, Arango J, Ali RA, Bohorquez EB, Lund AR, Ashwell Cm, Settar P, O'Sullivan NP, Koci MD. 2014. Genetic variation within the Mx gene of commercially selected chicken lines reveals multiple haplotypes, recombination and a protein under selection pressure. PLoS ONE 9 (9): e108054. DOI: 10.1371/journal.pone.0108054

Knap PW, Bishop SC. 2008. Relationship between genetic change and infectious disease in domestic livestock. An occasional publication of the British Society of Animal Science. Br Sec Anim Sci, Midlothian, UK.

Ko JH, Jin HK, Asano A, Takada A, Ninomiya A, Kida H, Hokiyama H, Ohara M, Tsuzuki M, Nishibori M, Mizutani M, Watanabe T. 2002. Polymorphisms and the differential antiviral activity of the chicken Mx gene. Genome Res 12: 595-601. DOI: 10.1101/gr.210702

Ko JH, Takada A, Mitsuhashi T, Agui T and Watanabe T. 2004. Native antiviral specificity of chicken Mx protein depends on amino acid variation at position 631. Anim Genet 35: 119-122. DOI: 10.1111/j.1365-2052.2004.01096.x

Livant EJ, Avendano S, McLeod S, Ye X, Lamont SJ, Dekkers JCM, Ewald SJ. 2007. MX1exon 13 polymorphisms in broiler breeder chickens and associations with commercial traits. Animal Genetics 38: 177-179. DOI: 10.1111/j.1365-2052.2007.01577.x

Maeda Y. 2005. Polymorphism of $M x$ gene in Asian indigenous chicken population. Proceedings of the International Symposium of Local Poultry in Indonesia, August 2005, Universitas Diponegoro, Semarang. [Indonesian]

Mahardhika IWS, Daryono BS. 2019. Phenotypic performance of Kambro crossbreeds of female broiler cobb 500 and male Pelung Blirik Hitam. Buletin Veteriner Udayana 11 (2): 188-202. DOI: 10.24843/bulvet.2019.v11.i02.p12

Pagala MA, Muladno C, Sumantri, Murtini S. 2013. Association of Mx gene genotype with antiviral and production traits in Tolaki chicken. Int J Poult Sci 12: 735-739. DOI: 10.3923/ijps.2013.735.739

Pagala MA, Saili T, Nafiu LO, Sandiah N, Baa LO, Aku AS, Zulkarnaen D, Kurniawan W. 2017. Polymorphism of Mx Hpy81 genes in native chickens observed using the PCR-RFLP technique. Int J Poult Sci 16 (9): 364-368. DOI: 10.3923/ijps.2017.364.368. ansinet.org/ijps

Pagala MA, Ulupi N. 2014. The detection Mx gene of Tolaki chicken using DNA extraction in different methods. J Ilmu Teknol Peternakan Trop 1: 1-8. [Indonesian]

Permatasari P, Sumantri C, Darwati S, Ulupi N. 2015. Polymorphisms of myxovirus gene in selected kampung chicken. Jurnal Ilmu Produksi dan Teknologi Hasil Peternakan 3 (1): 4-7. [Indonesian]

Pracoyo NE. 2009. Penyebab Infeksi AI A (H5N1) di Indonesia. Jurnal Ekologi Kesehatan 8 (4): 1094-1099. [Indonesian]

Sironi L, Ramelli P, Williams JL, Mariani P. 2010. PCR-RFLP genotyping protocol for chicken $M x$ gene G/A polymorphism associated with the S631N mutation. Genet Mol Res 9 (2):1104-1108. DOI: 10.4238/vol9-2gmr811.

Sulandari S, Zein MSA, Paryanti S, Sartika T, Astuti M, Widjastuti T, Sujana E, Darana S, Setiawan I, Garnida D. 2007. Sumber daya genetik ayam lokal Indonesia. In: Diwyanto K, Prijono SN (1 $1^{\text {st }}$ ed $)$ Keragaman sumber daya hayati ayam lokal indonesia: Manfaat dan potensi. Pusat Penelitian Biologi, LIPI, Indonesia. [Indonesian]

Tanjung A, Saragih HTSSG, Trijoko, Soenarwan HP, Widianto S, Mahardhika IWS, Daryono BS. 2019. Polymorphism of myostatin gene and its association with body weight traits in a hybrid of GAMA chicken (Gallus gallus domesticus Linn. 1758). Biodiversitas 20: 3207-3212. DOI: 10.13057/biodiv/d201113

Verhelst J, Hulpiau P, Saelens X. 2013. Mx proteins: Antiviral gatekeepers that restrain the uninvited. Microbiol Mol Biol R 77 (4): 551-566. DOI: 10.1128/MMBR.00024-13

Watanabe T. 2003. Genomic analysis of antiviral resistant Mx gene in the chicken. Proceedings of The International Workshop on Animal Genome Analysis. Sapporo, 16-17 September 2003. 